Reprinted from: Leafy Spurge, Monograph series of the Weed Science Society of America. ed. Alan K. Watson, 1985. Chapter 7 pp. 65-78. ill.

Published by: Weed Science Society of America. http://www.wssa.net/

\title{
Chemical control of leafy spurge
}

\author{
HAROLD P. ALLEY and CALVIN G. MESSERSMITH \\ Extension Specialist-Weed Science and Professor of Weed Science, University of Wyoming, retired, and Professor of \\ Agronomy, North Dakota State University, respectively
}

I. Introduction

II. Development of Herbicides

III. Current Herbicides and Research

Selective Herbicides

Nonselective Herbicides

IV. New Application Techniques

V. Chemical Control

Range and Pastureland

Cropland

Noncropland

Future Research Needs

Literature Cited

\section{Introduction}

Leafy spurge (Euphorbia esula L.) is a competitive and aggressive perennial plant that is very difficult and expensive to control. Its deep, tenacious root system, with the capacity to sprout from root segments and underground buds, along with the potential of the seed remaining viable for up to 8 years, is indicative of its persistent nature.

The weed has spread in recent years from small isolated areas to where it is reported to infest 1 million hectares in the United States and Canada. It is found from the best agricultural land to the rocky slopes and hillsides of low productive rangeland sites. Infestations range from solid stands where all other vegetation is virtually eliminated to isolated infestations that serve as a source of seed for spread and the subsequent infestation of additional areas.

Various methods of leafy spurge control have been evaluated. Cultural practices, although effective where methods can be employed, are not practical or adaptable to non- 
cultivated areas. Biological control is receiving much attention and should be an economical method to combat the spread of leafy spurge. However, biological control methods are not available, and it may be several years before effective biological programs are developed. It has been suggested that sheep be utilized to control and reduce the spread of leafy spurge; however, the use of sheep is not an accepted and widely used practice. Research is being conducted to substantiate earlier grazing studies and its feasibility as a control method. Thus, the use of herbicides to control and limit the spread of leafy spurge is the most prominent and widely used practice today and should be considered as a means of controlling and stopping its spread.

The greatest advances in leafy spurge control have come from the development of highly active and selective compounds that can be used within many environmental conditions. However, it must be recognized that herbicides are just another tool, or form of energy for combating weeds; they are not a panacea for eliminating our serious weed problems. Infestations of leafy spurge should be eradicated when the problem is small. It is a mistake to wait until thousands of hectares are infested under the misconception that the weed can be eliminated economically later with herbicides, grazing management or biological control methods. Seed production and seedling establishment can be prevented with available herbicides at reasonable application rates and expense, but control that reduces leafy spurge stands requires repeated treatments and (or) the use of expensive herbicides.

Most research reports evaluate a herbicide's efficacy by reduction in vegetative aboveground growth, but there has been a limited effort to determine the herbicide's effect on the underground reproductive system of perennial weeds. Topgrowth control is easy to evaluate, but it is laborious and time-consuming to obtain similar information on the underground vegetative system of perennial plants. To understand completely the value of any herbicide for reduction in stand and (or) elimination of leafy spurge, more emphasis must be directed toward control of underground plant parts.

Chemical control of leafy spurge is based on the nature of the infestation, because the methods suggested and the herbicides that can be used in range and pastureland, noncropped areas and cropped areas differ considerably. Consult local agricultural experiment station weed control guides or weed control specialists before using any herbicide.

\section{Development of herbicides}

The greatest advances in leafy spurge control have come from the development of selective herbicides applied at reasonably low rates. Progress can be traced from the early research in the United States in 1936 and 1937, which reported on the efficacy of sodium chlorate, atlacide, creosote, kerosene, sulfuric acid, ammonium thiocyanate, potassium chlorate, and fertilizers like kainite and barnyard manure. The addition of glue and sulfuric acid to sodium chlorate solutions to enhance physical contact between leaf surface and the spray solution was also researched $(8,16)$. These early investigators realized the importance of eliminating small patches of leafy spurge even though they did not have the arsenal of herbicides we have today. It is apparent their warnings were not heeded.

Page 2 of 19 
Bakke (8) reported that sodium chlorate was the most effective herbicide for eradication of leafy spurge. The following formula was effective when applied as a spray: sodium chlorate, $1.12 \mathrm{~kg}$; animal glue, $4 \mathrm{~g}$; sulfuric acid, $3 \mathrm{~cm}^{3}$; and water, $3.78 \mathrm{~L}$ applied to make the leaves dripping wet. Hanson (16) also stated that the best method of control was sodium chlorate. His recommendations were 11 to $23 \mathrm{~L}$ of solution per $\operatorname{rod}^{2}\left(5 \mathrm{~m}^{2}\right)$ at the first application, and a second and even a third application to any new plants that might appear. Sodium chlorate increased rapidly in use, despite the high cost and serious fire hazard, chiefly for deep-rooted perennial weed control in noncrop areas and small patches in cultivated fields. Idaho used a total of 1.8 million $\mathrm{kg}$ of chlorate from 1927 to 1935. Kansas used nearly 1.36 million $\mathrm{kg}$ annually from 1939 to 1940 (36).

The development and introduction of new herbicides progressed steadily after 1900 . However, the discovery of the phenoxyacetic acid herbicides in Britain and the United States from 1942 to 1944 ushered in the real beginning of the era of chemical weed control, as we know it today. In particular, 2,4-D [(2,4-dichlorophenoxy) acetic acid] was used for broadleaf annual and perennial weed control.

The chronology of new herbicides shows that the development of improved organic soil sterilizing herbicides progressed rapidly during the 1950's and 1960's, with the substituted ureas, uracils, chlorobenzoic acids, phenylacetic acid derivatives, $s$-triazines, triazoles, and other heterocyclic derivatives coming along almost simultaneously. Approximately 157 herbicides that have been tested thoroughly were included in the weed science list of common and chemical names in 1980.

The introduction of dicamba (3,6-dicloro-o-anisic acid) in 1962 and picloram (4amino-3,5,6-trichloropicolinic acid) in 1963, for public use, was responsible for renewed interest in research and leafy spurge control. Their activity at low rates added new impetus to the perennial weed control program. Although increased emphasis on research to find new compounds and evaluate herbicides combinations, growth regulators, additives, repetitive treatments, etc. are necessary, 2,4-D, dicamba and picloram are the most widely used herbicides for leafy spurge control, and there is no prospect of equally effective compounds in the near future.

\section{Current herbicides and research}

\section{Selective herbicides}

Phenoxy herbicides. The herbicide 2,4-D and its various formulations have been evaluated extensively for leafy spurge control. Rates of applications have ranged from 9.5 to $72 \mathrm{~kg}$ ai/ha. Treatments using 2,4-D were evaluated as early as 1948 (20). Leafy spurge treated with 2,4-D ester at 1.12 to $6.72 \mathrm{~kg} /$ ha during May and June of 1948 and retreated three times in 1949 and twice in 1950 gave top kill in proportion to the amount of 2,4-D applied. After seven treatments in 3 years the stand of leafy spurge was reduced 70, 85,90 and $95 \%$ with 2,4-D at 1.12, 2.24, 4.48 and $6.72 \mathrm{~kg} / \mathrm{ha}$, respectively. Bohmont (9) reported that control ranged from 0 to $65 \%$ from one treatment per year. Rates of 4.48 , 6.72 and $8.96 \mathrm{~kg} / \mathrm{ha}$ were more effective than lower concentrations. The $8.96 \mathrm{~kg} / \mathrm{ha}$ concentration was not significantly better than the $4.48 \mathrm{~kg} /$ ha treatment with good growing 
conditions at treatment, but 2,4-D at $8.96 \mathrm{~kg} / \mathrm{ha}$ of either the ester or amine formulation produced the best control under dry conditions. Repeated 2,4-D treatments at $2.24 \mathrm{~kg} / \mathrm{ha}$ (ester or amine) over a 4-year period controlled 25 to $45 \%$ of the original stand. In an experiment involving nine consecutive biannual herbicide applications, $2,4-\mathrm{D}$ at $2.24 \mathrm{~kg} / \mathrm{ha}$ reduced the leafy spurge stand $50 \%$ when evaluated one year after treatments were discontinued (30). Shafer (35) felt that better adsorption and distribution of 2,4-D throughout an extensive root system might be obtained by soil application. He reported almost complete leafy spurge elimination with $2,4-\mathrm{D}$ amine at $44.8 \mathrm{~kg} / \mathrm{ha}$ when soil-applied in the fall. Warden (41) reported that 2,4-D at $28 \mathrm{~kg} /$ ha reduced the stand $98 \%$ and the perennial grasses were adversely affected but recovered. However, the areas treated were completely reinfested with leafy spurge after 3 years. Fabricius (14) reported $100 \%$ control the first year from 2,4-D ester at $44.8 \mathrm{~kg} / \mathrm{ha}$, but the area was reinfested with leafy spurge seedlings the following year. Leafy spurge stand was reduced $95 \% 2$ years after treatment with 2,4-D at $71.7 \mathrm{~kg} / \mathrm{ha}$ (13). A summary of research conducted in Wyoming with various 2,4-D rates from 1952 through 1979 indicates similar results from only one application (38). Low 2,4-D rates of 1.12 to $2.24 \mathrm{~kg} /$ ha prevented seed production, rates from 2.24 to $6.72 \mathrm{~kg} /$ ha gave from 32 to $66 \%$ reduction in top growth, and high rates of 22.4 to $89.6 \mathrm{~kg} / \mathrm{ha}$ reduced the leafy spurge stand from 98 to $100 \%$ as evaluated 1 year following treatment.

Various state weed control guides, bulletins, leaflets and circulars that suggest 2,4-D uses for leafy spurge control are in agreement for expected control, but rates of application vary somewhat $(1,4,6,12,15,19,28)$. It is generally, suggested that $2,4-\mathrm{D}$ at 1.12 to $2.24 \mathrm{~kg} / \mathrm{ha}$ will control the aboveground stem tissue, will kill young seedlings and normally prevent seed production for that growing season. Applications to reduce established stands of leafy spurge require 2,4-D rates ranging from 2.24 to $8.96 \mathrm{~kg} / \mathrm{ha}$, applied at least twice during the growing season and over a 3- to 5-yr period. Reinfestation has been common after treatments were stopped.

Picloram. Picloram (4-amino-3,5,6-trichloro-picolinic acid) is the most consistent and effective herbicide available for control and eradication of leafy spurge. The compound's soil persistence, longevity of control and grass tolerance to rates commonly used is an added advantage of picloram over other herbicides on rangelands and grass pastures. The picloram residual reduces the need for immediate retreatment and number of subsequent retreatments necessary to reduce reinfestation from either seeds or emerging buds on root fragments.

Picloram was released to most research institutions in 1963 for evaluation. As early as 1964 (17) and 1965 (2), research reports indicated the potential of this herbicide for leafy spurge control. Heikes (17) stated that picloram at $2.24 \mathrm{~kg} /$ ha provided effective control for two seasons. Alley (2), in 1965, reported that both fall and spring applications were very effective. Evaluated 1 year after application, picloram at $1.12 \mathrm{~kg} / \mathrm{ha}$ resulted in 95 to $97 \%$ control, whereas $2.24 \mathrm{~kg} /$ ha was required for $100 \%$ control. Mitich (25) found that there was still 95\% control 3 years after application. Messersmith (29) obtained 94\% control with picloram at $2.24 \mathrm{~kg} / \mathrm{ha}$. Alley et al. (3), evaluating the longevity of control, found that all picloram treatments, whether granule, liquid or mixed with 2,4-D, had long soil residual, as indicated by outstanding control 3 years after treatment. Liquid picloram at $1.12 \mathrm{~kg} /$ ha gave a $99 \%$ reduction of leafy spurge the first year after application, but 
leafy spurge had reinfested the treated plots and only 55\% reduction in stand was recorded after 3 years. However, picloram at $2.24 \mathrm{~kg} / \mathrm{ha}$ maintained $98 \%$ control after 3 years. The $2 \%$ granule formulation was more effective than the liquid. All other liquid formulations in combination with 2,4-D performed comparable to equivalent rates of picloram alone. Bowes and Molberg (10) studied the longevity of control and found that picloram reduced the number of leafy spurge shoots for 4 years after treatment regardless of rate applied, and the reduction in leafy spurge population increased as the picloram rate was increased from 0.6 to $2.2 \mathrm{~kg} / \mathrm{ha}$. However, once the plants started to reestablish, the population of shoots increased rapidly in all plots, including those receiving the highest rate of application. They further stated that picloram will control leafy spurge effectively and prevent seed set for several years before regrowth occurs. Bybee (11) found that reestablishment was approximately $40 \%$ of the original stand with picloram at 1.12 $\mathrm{kg} / \mathrm{ha}$ and approximately $10 \%$ of the original stand with picloram at 2.24 and $4.48 \mathrm{~kg} / \mathrm{ha}$ 2 and 3 years after a single treatment.

An extensive repetitive herbicide treatment program for leafy spurge control was initiated in 1978 (37), and the effects of original and retreatments on leafy spurge shoot and root control has been evaluated since the initiation of the research $(38,39,40)$. Three years after treatment, liquid picloram at 1.12 and $2.24 \mathrm{~kg} / \mathrm{ha}$ maintained 84 and $90 \%$ top growth control, respectively (38). Four years after treatment, shoot control had decreased to 78 and $85 \%$ on the same treatment plots (Table 1). It is interesting that plots treated with picloram and re-treated with picloram in subsequent years controlled 99 to $100 \%$ of the shoot growth. An original treatment of picloram, liquid or $2 \%$ granule, at $0.56 \mathrm{~kg} / \mathrm{ha}$, which was re-treated for 3 consecutive years with picloram liquid at $0.56 \mathrm{~kg} / \mathrm{ha}$ was maintaining 99\% shoot growth control when evaluated in 1982. Retreatments with dicamba, 2,4-D, or dicamba + 2,4-D were not as effective (Figure 1, Table 1).

Figure 1. Percentage leafy spurge shoot control resulting from original treatments made in 1978 and retreatments applied in 1979 and 1980. Evaluations made in 1981, Driskill Ranch, Crook County, Wyoming.




Table 1. Effects of original treatments and retreatments as evaluated by live shoot regrowth of leafy spurge, Driskill Ranch, Crook County, WY.

\begin{tabular}{|c|c|c|c|c|c|c|}
\hline \multirow[b]{3}{*}{$\begin{array}{l}\text { Original }^{1} \\
\mathrm{~kg} \mathrm{ai} / \mathrm{ha}\end{array}$} & \multicolumn{6}{|c|}{ Percent shoot control } \\
\hline & \multicolumn{6}{|c|}{ Retreatment, kg ai/ha } \\
\hline & $\begin{array}{c}\text { 2,4-D amine } \\
2.24\end{array}$ & $\begin{array}{c}\text { Picloram } \\
\text { K salt } 0.56\end{array}$ & $\begin{array}{c}\text { Dicamba } \\
4 \mathrm{~L} \\
2.24\end{array}$ & Check & $\begin{array}{l}\text { Picloram K } \\
\text { salt } \\
1.12\end{array}$ & $\begin{array}{c}\text { Dicamba } 4 \mathrm{~L} \\
1.12 \\
2,4-\mathrm{D} \text { amine } \\
2.24\end{array}$ \\
\hline $\begin{array}{l}\text { Picloram (K salt) } \\
2.24\end{array}$ & 94 & 100 & 98 & 85 & 100 & 97 \\
\hline $\begin{array}{l}\text { Picloram (K salt) } \\
1.12\end{array}$ & 82 & 99 & 96 & 78 & 100 & 98 \\
\hline $\begin{array}{l}\text { Picloram (K salt) } \\
0.56\end{array}$ & 86 & 99 & 89 & 55 & 100 & 85 \\
\hline $\begin{array}{l}\text { Picloram ( } 2 \% \text { beads }) \\
2.24\end{array}$ & 87 & 99 & 97 & 85 & 100 & 98 \\
\hline $\begin{array}{l}\text { Picloram ( } 2 \% \text { beads }) \\
1.12\end{array}$ & 85 & 99 & 96 & 56 & 100 & 88 \\
\hline $\begin{array}{l}\text { Picloram ( } 2 \% \text { beads }) \\
0.56\end{array}$ & 73 & 99 & 69 & 58 & 100 & 91 \\
\hline $\begin{array}{l}\text { Picloram/2,4-D (amine) } \\
2.24+4.48\end{array}$ & 88 & 99 & 96 & 51 & 100 & 95 \\
\hline $\begin{array}{l}\text { Picloram/2,4-D (amine) } \\
1.12+2.24\end{array}$ & 81 & 98 & 94 & 45 & 100 & 91 \\
\hline $\begin{array}{l}\text { Picloram/2,4-D (amine) } \\
0.56+1.12\end{array}$ & 75 & 98 & 84 & 0 & 100 & 88 \\
\hline $\begin{array}{l}\text { Dicamba 4L } \\
8.96\end{array}$ & 87 & 98 & 95 & 61 & 100 & 98 \\
\hline $\begin{array}{l}\text { Dicamba 4L } \\
4.48\end{array}$ & 78 & 98 & 88 & 36 & 100 & 90 \\
\hline Check & 63 & 97 & 92 & 0 & 100 & 84 \\
\hline
\end{tabular}

${ }^{1}$ Original treatments applied May 25, 1978; retreatments applied June 21, 1979, May 13, 1980, May 19, 1981; evaluated May 19, 1982.

Topgrowth control of leafy spurge resulting from various formulations and rates of picloram application are well documented, but the root kill resulting from various treatments is not as well documented. Leafy spurge roots were found to a depth of at least $1.83 \mathrm{~m}$ in a soil that had received picloram at $2.2 \mathrm{~kg} / \mathrm{ha} \mathrm{(10).} \mathrm{Vore} \mathrm{and} \mathrm{Alley} \mathrm{(38)} \mathrm{found} \mathrm{a}$ maximum depth of root kill to be $0.4 \mathrm{~m}$ when excavating selected old established leafy 
spurge plants that had received a $2.2 \mathrm{~kg} /$ ha picloram treatment. However, further soil probing indicated that reduction of live roots in the soil profile from 0 to $0.8 \mathrm{~m}$ was comparable to the reduction in shoot growth. Picloram liquid at $2.24 \mathrm{~kg} / \mathrm{ha}$ was maintaining 96\% shoot growth reduction 2 years after treatment, while the root reduction was $90 \%$. Picloram liquid applied at $1.2 \mathrm{~kg} / \mathrm{ha}$ in 1978 and reapplied at 0.56 or $1.12 \mathrm{~kg} / \mathrm{ha}$ in 1979 controlled 96 to $99 \%$ of the shoot growth and 98 to $99 \%$ of the root growth when evaluated in 1980 (Table 2).

There is a need to continue and to evaluate, further the longevity of control from original and retreatment programs, both for vegetative top growth control and reduction of the root potential.

Dicamba. Dicamba (3,6-dichloro-o-anisic acid) has been evaluated extensively as individual treatments at various rates of application, in combination with 2,4-D, and as a herbicide for retreatment potential.

A summary of treatment efficacy of dicamba at 2.24 to $8.96 \mathrm{~kg} / \mathrm{ha}$ from 1965 through 1978 throughout Wyoming indicates a wide variation in percentage control of leafy spurge top growth (38). Evaluations 1 and 2 years after application resulted in an average control ranging from $32 \%$ by $2.24 \mathrm{~kg} / \mathrm{ha}$ to $91 \%$ control by $8.96 \mathrm{~kg} / \mathrm{ha}$. Control decreased from all treatments after 2 years. Mitich (25) reported that dicamba at $4.48 \mathrm{~kg} / \mathrm{ha}$ gave $58 \%$ control 3 years after treatment. Messersmith (29), in a 1974 research report, stated that dicamba granular formulation gave consistently higher control than dicamba liquid formulations 1 year after application. Dicamba granule at $8.96 \mathrm{~kg} / \mathrm{ha}$ gave $88 \%$ control and dicamba liquid at the same rate gave $66 \%$ control. Percentage control was reduced when compared with evaluations made 9 months after treatment. However, the same researcher reported that all formulations of dicamba above $2.24 \mathrm{~kg} / \mathrm{ha}$ gave satisfactory control of leafy spurge the first year, but gave unsatisfactory control the second year. Dicamba $5 \mathrm{G}$ at $11.2 \mathrm{~kg} / \mathrm{ha}$ gave $85 \%$ control and liquid formulations averaged $12 \%$ better control than granular formulations at the same rate the second year (31). Granular formulations were reported to cause more grass damage and stand reduction than liquid formulations (5).

Dicamba treatments reportedly have been effective only during one growing season, depending upon the herbicide used and the rate of application. Thus, retreatment is needed to continue reducing the stand density and seed bank. Mitich $(24,26,27)$ established several 3-year experiments to evaluate retreatments, and reported that percentage control did not improve substantially from the first evaluation during the year of treatment to the last evaluation. Percentage control was lowest with 2,4-D, moderate for dicamba and highest for picloram. Robinson's (34) results were similar to those reported by Mitich. However, initial applications made in the fall and re-treated in the spring were more effective than spring initial and fall retreatment. Vore and Alley (38) found that dicamba liquid at 4.48 and $8.96 \mathrm{~kg} / \mathrm{ha}$ was maintaining 42 and $66 \%$ leafy spurge control 2 years after application. A retreatment of dicamba liquid at $2.24 \mathrm{~kg} / \mathrm{ha}$ over the original treatments of dicamba liquid, for 3 successive years, resulted in 88 and $95 \%$ reduction in the shoot regrowth when evaluated in 1982 (Table 1). 
Table 2. Effect of selected original treatments and selected retreatments as evaluated by leafy spurge regrowth and root control and presence at various soil depths, Driskill Ranch, Crook County, WY.

\begin{tabular}{|c|c|c|c|c|c|c|c|c|c|}
\hline \multirow[b]{2}{*}{ Original } & \multirow[b]{3}{*}{$\mathrm{kg}$ ai/ha } & & & \multicolumn{5}{|c|}{ Root segments $/ 0.3 \mathrm{~m}^{3}$} & \multirow{3}{*}{$\begin{array}{l}\begin{array}{l}\text { Root wt } \\
\mathrm{g} / 0.3 \mathrm{~m}^{3}\end{array} \\
0-0.8 \mathrm{~m}\end{array}$} \\
\hline & & \multicolumn{2}{|c|}{$\%$ Control $^{1}$} & \multicolumn{5}{|c|}{ Depth zone (m) } & \\
\hline Retreatment & & Shoot & Root & $0-0.2$ & $0.2-0.4$ & $0.4-0.6$ & $0.6-0.8$ & $0-0.8$ & \\
\hline Picloram-K salt & 1.12 & & & & & & & & \\
\hline picloram-K & 0.56 & 96 & 98 & 0.8 & 4.6 & 4.6 & 9.2 & 19.2 & 4.6 \\
\hline picloram-K & 1.12 & 99 & 99 & 0 & 0.8 & 1.5 & 2.3 & 4.6 & 0.4 \\
\hline dicamba $4 \mathrm{~L}$ & 2.24 & 96 & 92 & 17.6 & 12.2 & 14.5 & 26.7 & 71.0 & 4.5 \\
\hline None & - & 94 & 96 & 2.3 & 10.7 & 4.6 & 16.8 & 34.4 & 4.2 \\
\hline Picloram-K salt & 2.24 & & & & & & & & \\
\hline picloram-K & 0.56 & 99 & 94 & 10.7 & 6.1 & 12.2 & 22.9 & 51.9 & 13.2 \\
\hline picloram-K & 1.12 & 99 & 87 & 1.5 & 26.0 & 34.4 & 63.4 & 125.3 & 10.1 \\
\hline dicamba 4L & 2.24 & 98 & 73 & 36.7 & 45.1 & 80.2 & 90.9 & 252.9 & 32.8 \\
\hline None & - & 96 & 90 & 0.8 & 6.1 & 17.6 & 64.9 & 89.4 & 8.6 \\
\hline Picloram- $2 \%$ beads & 1.12 & & & & & & & & \\
\hline picloram-K & 0.56 & 99 & 97 & 0 & 9.2 & 7.6 & 11.4 & 28.2 & 3.3 \\
\hline picloram-K & 1.12 & 98 & 91 & 6.1 & 11.4 & 26.7 & 37.4 & 81.6 & 3.2 \\
\hline dicamba 4L & 2.24 & 87 & 81 & 35.9 & 27.4 & 61.9 & 45.1 & 180.3 & 42.0 \\
\hline None & - & 51 & 76 & 19.9 & 68.8 & 71.0 & 63.4 & 223.1 & 21.3 \\
\hline Picloram- $2 \%$ beads & 2.24 & & & & & & & & \\
\hline picloram-K & 0.56 & 98 & 97 & 0 & 10.7 & 10.7 & 9.9 & 31.3 & 3.2 \\
\hline picloram-K & 1.12 & 100 & 93 & 0 & 3.0 & 26.7 & 34.4 & 64.1 & 5.8 \\
\hline dicamba 4L & 2.24 & 96 & 97 & 11.4 & 2.3 & 4.6 & 7.6 & 25.9 & 10.5 \\
\hline None & - & 95 & 99 & 1.5 & 1.5 & 1.5 & 3.8 & 8.3 & 0.5 \\
\hline Dicamba 4L & 8.96 & & & & & & & & \\
\hline picloram-K & 0.56 & 87 & 89 & 14.5 & 26.0 & 25.9 & 27.5 & 103.9 & 10.8 \\
\hline picloram-K & 1.12 & 98 & 98 & 4.6 & 1.5 & 1.5 & 11.4 & 19.0 & 8.3 \\
\hline dicamba 4L & 2.24 & 89 & 94 & 9.9 & 13.8 & 3.0 & 24.4 & 51.1 & 12.4 \\
\hline None & - & 66 & 89 & 13.0 & 27.5 & 24.4 & 33.6 & 98.5 & 11.4 \\
\hline None & - & & & & & & & & \\
\hline picloram-K & 0.56 & 96 & 58 & 77.9 & 131.5 & 103.9 & 79.4 & 392.6 & 33.6 \\
\hline picloram-K & 1.12 & 93 & 81 & 26.7 & 53.5 & 48.1 & 46.6 & 174.9 & 13.7 \\
\hline dicamba 4L & 2.24 & 72 & 61 & 139.0 & 99.3 & 68.8 & 59.6 & 366.7 & 22.9 \\
\hline None & - & 0 & 0 & 342.2 & 166.5 & 221.5 & 206.3 & 936.5 & 47.3 \\
\hline
\end{tabular}

${ }^{1}$ Shoot evaluation May 12, 1980; root evaluation July 30, 1980. 
Table 3. Leafy spurge control in 1975 and 1976 after 2,4-D and dicamba treatments were discontinued in the spring of 1974.

\begin{tabular}{|c|c|c|c|c|c|c|c|c|}
\hline \multirow{3}{*}{$\begin{array}{c}\text { Dicamba } \\
\text { rate } \\
(\mathrm{kg} / \mathrm{ha})\end{array}$} & \multirow{3}{*}{$\begin{array}{c}\text { Time } \\
\text { of } \\
\text { evaluation }\end{array}$} & \multicolumn{7}{|c|}{ Percent control $^{1}$} \\
\hline & & \multicolumn{6}{|c|}{ 2,4-D rate $(\mathrm{kg} / \mathrm{ha})$} & \multirow[b]{2}{*}{ Mean $^{3}$} \\
\hline & & 0 & 0.28 & 0.56 & 0.84 & 2.24 & 4.48 & \\
\hline \multirow[t]{5}{*}{$\overline{0}$} & Spring 1975 & $-50^{2}$ & 1 & -21 & 25 & 16 & 23 & -1 \\
\hline & Fall 1975 & 35 & 32 & 41 & 59 & 57 & 65 & 48 \\
\hline & Spring 1976 & -3 & -26 & -15 & 21 & 23 & 44 & 7 \\
\hline & Fall 1976 & 3 & -16 & 2 & 3 & -11 & 25 & 1 \\
\hline & Mean & -4 & -2 & 2 & 27 & 21 & 39 & $14 \mathrm{~b}$ \\
\hline \multirow[t]{5}{*}{0.28} & Spring 1975 & -49 & 45 & 4 & -14 & 36 & 24 & 8 \\
\hline & Fall 1975 & 32 & 39 & 54 & 43 & 57 & 64 & 48 \\
\hline & Spring 1976 & 4 & 7 & 8 & 13 & 32 & 40 & 17 \\
\hline & Fall 1976 & 20 & -33 & -19 & -42 & -14 & 9 & -13 \\
\hline & Mean & 2 & 14 & 12 & 0 & 28 & 34 & $15 \mathrm{ab}$ \\
\hline \multirow[t]{5}{*}{0.56} & Spring 1975 & -39 & 6 & 15 & 3 & 35 & 54 & 12 \\
\hline & Fall 1975 & 49 & 27 & 49 & 58 & 70 & 71 & 54 \\
\hline & Spring 1976 & -4 & 8 & 23 & 23 & 43 & 43 & 23 \\
\hline & Fall 1976 & -41 & -21 & 14 & -1 & 0 & 11 & -6 \\
\hline & Mean & -9 & 5 & 25 & 21 & 38 & 45 & $21 \mathrm{ab}$ \\
\hline \multirow[t]{5}{*}{0.84} & Spring 1975 & -19 & 32 & -39 & 46 & 56 & 54 & 22 \\
\hline & Fall 1975 & 43 & 62 & 42 & 51 & 63 & 68 & 55 \\
\hline & Spring 1976 & 17 & 29 & -7 & 13 & 41 & 44 & 23 \\
\hline & Fall 1976 & 4 & -14 & -19 & 11 & 6 & 22 & 2 \\
\hline & Mean & 11 & 27 & -6 & 30 & 42 & 47 & $25 \mathrm{a}$ \\
\hline \multicolumn{2}{|c|}{ Overall Mean ${ }^{3}$} & $0 \mathrm{y}$ & $10 x y$ & $8 x y$ & $20 x y$ & $32 x y$ & & \\
\hline
\end{tabular}

${ }^{1} \operatorname{LSD}(0.05)$ level for 2,4-D $x$ dicamba interaction is $27 \%$.

${ }^{2} \mathrm{~A}$ negative number indicates an increase in plant stand from the initial stand count.

${ }^{3}$ Values in a column or row followed by the same letter or letters are not significantly different at the 0.05 level LSD.

Bybee (11), comparing combination and additive treatments applied biannually for 4.5 years, found dicamba applied at $0.84 \mathrm{~kg} / \mathrm{ha}$ resulted in only $43 \%$ leafy spurge control, but the same rate of dicamba with $2,4-\mathrm{D}$ at $4.48 \mathrm{~kg} / \mathrm{ha}$ controlled $91 \%$ of the leafy spurge. Leafy spurge in the 2,4-D and dicamba combination experiments reestablished to the original leafy spurge density 1 to 2 years after treatment (Table 3 ).

\section{Nonselective herbicides}

Glyphosate. Glyphosate [N-(phosphonomethyl)glycine] is a postemergence, nonselective herbicide that controls a broad spectrum of annual and perennial grass and 
broadleaf weed species with very limited soil persistence. It is recommended and cleared for the control of several perennial broadleaf and grass weeds in cropping systems before emergence of the crop and in industrial and noncrop areas. The compound's activity toward grass species does not make it a good candidate for leafy spurge control on pasture and rangeland sites. Vore and Alley (38) reported from 35 to $90 \%$ reduction in top growth control of leafy spurge with glyphosate at from 1.12 to $4.48 \mathrm{~kg} / \mathrm{ha}$ over a 2-year period. However, at rates higher than $2.24 \mathrm{~kg} / \mathrm{ha}$, a $50 \%$ or greater grass reduction was common.

Fall applications of glyphosate at 1.12 to $2.24 \mathrm{~kg} / \mathrm{ha}$ have given $90 \%$ or more control of leafy spurge. The optimum date of treatment appears to be in August or September. Messersmith (30) reports that fall treatments are nearly twice as effective as June or early July treatments. Follow-up treatments are necessary since there is no soil activity from glyphosate.

Soil Sterilants. When leafy spurge is confined to small, well-defined areas, certain highly active and selective herbicides, such as picloram, dicamba and even high rates of 2,4-D, may be a better selection than nonselective chemicals, commonly called soil sterilants, which eliminate all vegetative growth from the treated area.

Nonselective soil sterilants, such as the ureas, uracils, triazines, chlorates, borates, and other compounds containing mixtures of borates and chlorates, are available and can be used on small patches if bare ground can be tolerated. Fenac $[(2,3,6-$ trichlorophenyl)acetic acid] at 11.2 to $22.4 \mathrm{~kg} / \mathrm{ha}$, sodium chlorate at 5.6 to $11.2 \mathrm{~kg} / 5 \mathrm{~m}^{2}$, ureabor (mixture of sodium tetraborate + monuron) at 2.24 to $4.48 \mathrm{~kg} / 5 \mathrm{~m}^{2}$, and atrazine [2-chloro-4-(ethylamino)-6-iso-propylamino-s-triazine] at 0.14 to $0.28 \mathrm{~kg} / 5 \mathrm{~m}^{2}$ have consistently given from 95 to $100 \%$ control, with the longevity of control depending upon the rate of application (38). Where soil sterilants have removed all other vegetation, there is no competition to reinfestation of the area by annual and eventually perennial weeds as the sterilant dissipates from the soil.

\section{New application techniques}

The roller, controlled droplet application (CDA), and modified wick application techniques have received limited evaluation as methods for reducing the amount of herbicide applied while maintaining satisfactory leafy spurge control.

The roller and modified wick applicators have the potential of reducing the amount of herbicide required per hectare because the treatment is applied only to the leafy spurge plants infesting a specific area rather than to the entire area with conventional broadcast application. These methods also have the potential of reducing environmental contamination and allow specific herbicides to be used in areas where conventional application methods would cause damage or death to desirable plant species and contaminate water sources.

CDA (Herbi) shows promise for use by ground crews treating inaccessible areas where bulky granules or large volumes of liquid formulations are utilized. Limited research has been conducted using the CDA micron applicator. However, Alley et al. (7), evaluating plots 2 years after application, reported percentage control by the CDA com- 
parable to the conventional knapsack application, which applied approximately 10 times as much carrier per hectare as the CDA. Picloram at 1.12 and $2.24 \mathrm{~kg} / \mathrm{ha}$ was applied in a total volume of $35.5 \mathrm{~L} / \mathrm{ha}$ with the CDA and in $374 \mathrm{~L} / \mathrm{ha}$ with the knapsack. The fine droplets produced by the CDA moved off the target area with air movement less than 3.2 to $4.3 \mathrm{~km} / \mathrm{h}$ whereas drift was not apparent with the knapsack. Lym and Messersmith (22) reported that picloram at $0.13 \mathrm{~kg} / \mathrm{ha}$ applied with the CDA gave $100 \%$ top growth control for the year of application.

Messersmith and Lym $(23,32)$ have conducted considerable research comparing the roller (Figure 2) and modified wick applicators (33) (Figure 3) to conventional broadcast applications of picloram and glyphosate. Their first experiment established in 1978 and evaluated the following year showed picloram at $2.24 \mathrm{~kg} / \mathrm{ha}$ applied broadcast and the same concentration applied with the roller applicator provided similar top growth control. Picloram was more effective than glyphosate.

The results of a subsequent experiment are presented in Table 4. Picloram at $2.24 \mathrm{~kg} / \mathrm{ha}$ broadcast provided $100 \%$ control in the year after treatment, and control had decreased steadily to $85 \%$ by the end of the third year. The roller-applied treatments and picloram at $1 \mathrm{lb} / \mathrm{A}$ broadcast provided similar leafy spurge control for 1 year, but the roller-applied treatments generally provided better control 2 and 3 years after application than picloram at 1 $\mathrm{lb} / \mathrm{A}$ broadcast.

The roller and modified wick applicators have been compared in subsequent experiments. Leafy spurge control with picloram has tended to be higher when rollerapplied rather than wick-applied (Table 5). The 1:1 (picloram:water) solution concentration provided the highest leafy spurge control into June 1982 with both applicators. However, the 1:3 solution concentration may be the most efficient mixture, because
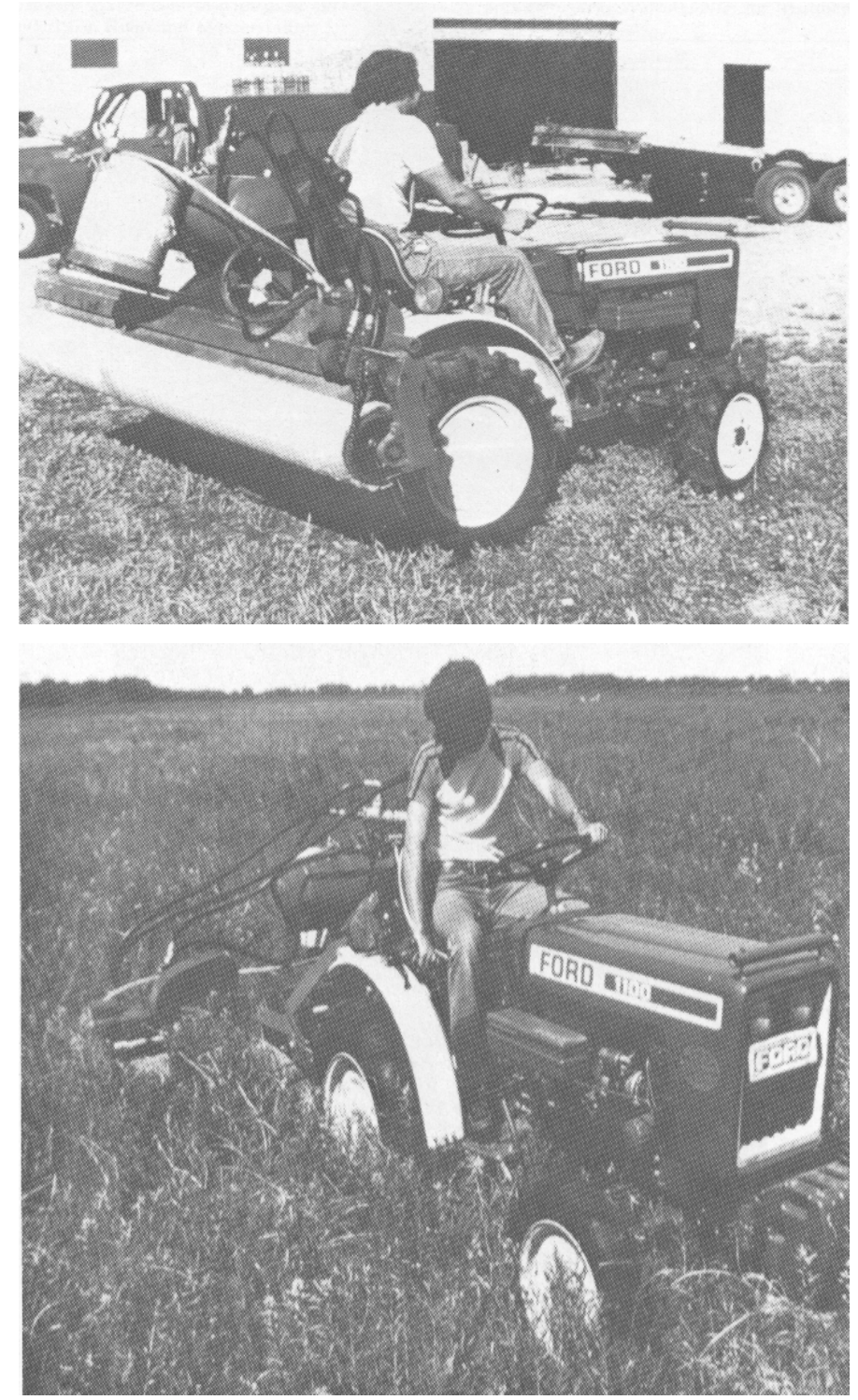

Figure 2. The roller applicator showing carpet covered roller and herbicide reservoir (above) and treating the top half of leafy spurge stems in a pasture (below). 
both $1: 1$ and $1: 3$ solution concentrations provided similar leafy spurge control through 1981 and retreatment would have been recommended for all treatments in 1982.

Estimates of the amount of herbicide applied with the roller and wick applicators were obtained by treating from 0.2 to 0.6 hectares that had an $80 \%$ or greater leafy spurge infestation (32). When compared to broadcast treatments of $2.24 \mathrm{~kg} / \mathrm{ha}$, the roller applied 30 to $33 \%$ as much herbicide and the wick applicators applied 17 to $25 \%$ as much (Table 6). This represents a reduction in herbicide use of 50 to $70 \%$ with the roller applicator and 75 to $80 \%$ with the wick applicator.

These experiments indicate the roller applicator is an effective method of applying picloram for leafy spurge control and the wick applicator shows promise. Both methods should be evaluated further.

Vore, unpublished data, and Lueschen et al. (21) found that some herbicides and herbicide concentrations appeared to wick slower than others. Picloram completely plugged the nylon rope most commonly used in the different ropewick applicators. The modified wick applicators used by Messersmith and Lym corrected this problem (Figure 3).
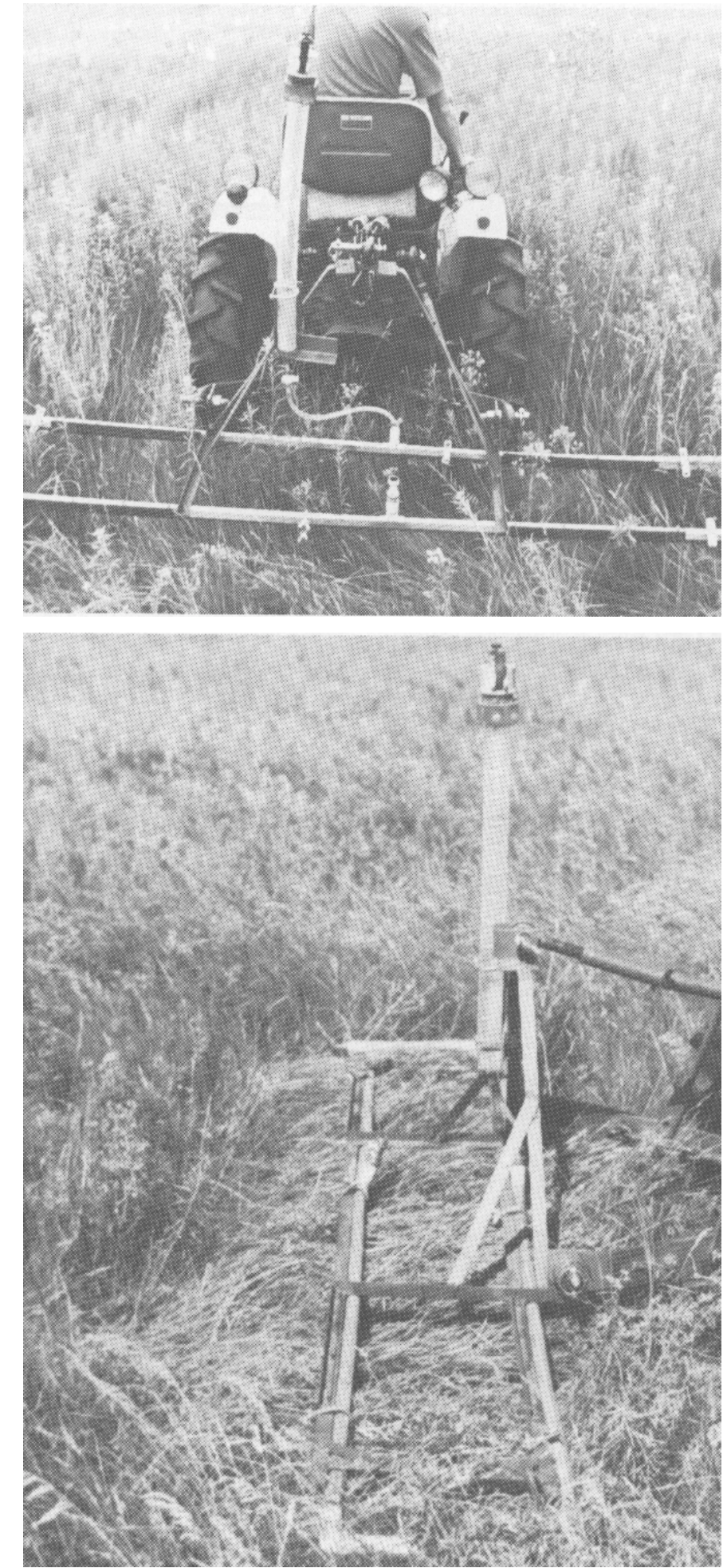

Figure 3. The wick applicator showing the doublebar frame and the sealed reservoir from the rear view (above), and the side view (below) showing that leafy spurge is treated by both the front and back wicks. 
Table 4. Leafy spurge control with picloram using the roller applicator near Walcott, ND, for treatments applied October 3, 1979. (Lym and Messersmith).

\begin{tabular}{|c|c|c|c|c|c|c|}
\hline \multirow{3}{*}{$\begin{array}{l}\text { Type of } \\
\text { application }\end{array}$} & \multirow{3}{*}{$\begin{array}{l}\text { Rate }^{1} \\
\text { (kg/ha) }\end{array}$} & \multicolumn{5}{|c|}{ Control } \\
\hline & & May & June & May & Aug. & June \\
\hline & & 1980 & 1980 & 1981 & 1981 & 1982 \\
\hline & \multicolumn{6}{|c|}{ 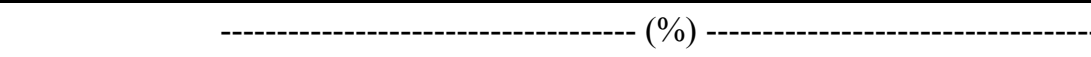 } \\
\hline Broadcast & 1.12 & 99 & 79 & 59 & 19 & 6 \\
\hline Broadcast & 2.24 & 100 & 100 & 98 & 96 & 85 \\
\hline Roller - $1.6 \mathrm{~km} / \mathrm{hr}$ & 2.24 & 99 & 80 & 61 & 43 & 34 \\
\hline Roller - $3.2 \mathrm{~km} / \mathrm{hr}$ & 2.24 & 94 & 77 & 70 & 53 & 24 \\
\hline LSD $(0.05)$ & & 6 & 13 & 19 & 32 & 28 \\
\hline
\end{tabular}

${ }^{1}$ Solution concentration on the roller was the same as $2.24 \mathrm{~kg} / \mathrm{ha}$ at $79.5 \mathrm{~L} / \mathrm{ha}$ broadcast (picloram (Tordon 22K):water $=1: 7.5 \mathrm{v}: \mathrm{v})$.

Table 5. Leafy spurge control with variable picloram concentrations using the roller and wick applicators with treatments applied on June 16, 1980, at Sheldon and September 2, 1980, at Valley City. (Lym and Messersmith).

\begin{tabular}{|c|c|c|c|c|c|c|c|}
\hline \multirow{3}{*}{ Applicator } & \multirow[b]{3}{*}{$\begin{array}{c}\text { Picloram } \\
\text { concentration }\end{array}$} & \multicolumn{6}{|c|}{ Location/evaluation date } \\
\hline & & \multicolumn{3}{|c|}{ Sheldon } & \multicolumn{3}{|c|}{ Valley City } \\
\hline & & May & Aug. & $\begin{array}{l}\text { June } \\
1982\end{array}$ & $\begin{array}{l}\text { June } \\
1981\end{array}$ & $\begin{array}{l}\text { Sept. } \\
1981\end{array}$ & $\begin{array}{l}\text { June } \\
1982\end{array}$ \\
\hline & & \multicolumn{6}{|c|}{ - } \\
\hline Roller & $1: 1$ & 90 & 58 & 59 & 96 & 93 & 65 \\
\hline Roller & $1: 3$ & 93 & 48 & 40 & 97 & 81 & 34 \\
\hline Roller & $1: 7$ & 75 & 15 & 17 & 91 & 50 & 15 \\
\hline Roller & $1: 11$ & 70 & 9 & 4 & 67 & 15 & 6 \\
\hline Roller & $1: 15$ & 69 & 12 & 6 & 35 & 3 & 2 \\
\hline Wick & $1: 1$ & 88 & 38 & 43 & 96 & 92 & 40 \\
\hline Wick & $1: 3$ & 80 & 18 & 8 & 93 & 78 & 16 \\
\hline Wick & $1: 7$ & 41 & 2 & 0 & 79 & 28 & 3 \\
\hline Wick & $1: 11$ & 49 & 8 & 3 & 68 & 5 & 0 \\
\hline Wick & $1: 15$ & 62 & 5 & 0 & 15 & 0 & 0 \\
\hline $\operatorname{LSD}(0.05)$ & & 14 & 21 & 30 & 17 & 28 & 32 \\
\hline
\end{tabular}

${ }^{1}$ Picloram (Tordon 22K): water (v:v). 
Table 6. Estimates of the amount of herbicides applied per acre on leafy spurge using the roller and wick applicators at various sites in North Dakota.

\begin{tabular}{|c|c|c|c|c|c|}
\hline \multirow[b]{2}{*}{$\begin{array}{l}\text { Application } \\
\text { method } \\
\text { and location }\end{array}$} & \multirow[b]{2}{*}{$\begin{array}{l}\text { Size of area } \\
\text { treated } \\
\text { (ha) })^{1}\end{array}$} & \multirow[b]{2}{*}{$\begin{array}{l}\text { Volume applied } \\
\text { (L) }\end{array}$} & \multirow[b]{2}{*}{$\begin{array}{c}\text { Herbicide and } \\
\text { concentration (v:v) } \\
\text { (herbicide:water) }^{2}\end{array}$} & \multicolumn{2}{|c|}{ Rate applied } \\
\hline & & & & $\mathrm{kg} / \mathrm{ha}^{3}$ & $\begin{array}{c}\% \text { of } \\
\text { broadcast } \\
\text { rate }^{4}\end{array}$ \\
\hline \multicolumn{6}{|l|}{ Roller } \\
\hline $\begin{array}{c}\text { Valley City } \\
\text { (1979) }\end{array}$ & 0.31 & 11.35 & picloram (1:7.5) & 1.0 & 44 \\
\hline Sheldon & 0.33 & 7.57 & picloram (1:7) & 0.67 & 30 \\
\hline $\begin{array}{l}\text { Valley City } \\
\text { (1980) }\end{array}$ & 0.27 & 10.97 & dicamba $(1: 7)$ & 2.4 & 53 \\
\hline Tolna & 0.32 & 11.35 & picloram (1:7) & 1.0 & 47 \\
\hline Minot & 0.40 & 10.0 & picloram (1:7) & 0.74 & 33 \\
\hline \multicolumn{6}{|l|}{ Wick } \\
\hline Sheldon & 0.66 & 4.12 & picloram (1:3) & 0.36 & 17 \\
\hline Tolna & 0.19 & 3.40 & picloram (1:3) & 0.50 & 23 \\
\hline Minot & 0.40 & 3.78 & picloram $(1: 3)$ & 0.56 & 25 \\
\hline \multicolumn{6}{|c|}{${ }^{1}$ Areas had $80 \%$ or greater infestation of leafy spurge. } \\
\hline $\begin{array}{l}{ }^{2} \text { Picloram (Tordon } \\
{ }^{3} \quad \mathrm{~kg} / \mathrm{ha}\end{array}$ & $\begin{array}{l}2 \mathrm{~K}) \text { contained } 0 . \\
\text { [total solution volur } \\
\end{array}$ & $\begin{array}{l}\mathrm{kg} / \mathrm{L} \text { and dicamba }(\mathrm{E} \\
\frac{\text { applied (L)][herbicice: }}{\text { area (hectares) }}\end{array}$ & $\begin{array}{l}\text { anvel) contained } 0.48 \mathrm{~kg} \\
\text { ater cone. }(\mathrm{kg} \mathrm{ai} / \mathrm{L})]\end{array}$ & & \\
\hline
\end{tabular}

\section{Chemical control}

\section{Range and pastureland}

The majority of the range and pastureland infested with leafy spurge is not adaptable to cultural practices. This situation dictates the use of selective herbicides to reduce the stand of large infestation and (or) elimination of the source of infestation from isolated, small patches.

Picloram is the most consistent and effective herbicide available for control and eradication of leafy spurge. Picloram at $2.24 \mathrm{~kg} /$ ha is needed for consistency and longevity of control. Lower rates are not as effective and reinfestation and (or) recovery occurs in a shorter period of time; thus subsequent annual applications would be required sooner and over a longer period of time. Fall application of picloram is usually more consistent than spring or early summer application. The granular formulation has been more effective than the liquid formulation where there are dense stands of old foliage, probably because of the amount of picloram reaching the soil. Granular formulations of picloram have been more damaging to the associated grass species than equivalent rates of the liquid formulations. Retreatment of leafy spurge seedlings with 2,4-D or low rates of 
dicamba or combinations of the two are the most common retreatments used and should be considered in a reduction or eradication program.

In recent repetitive treatments conducted by Vore and Alley (Table 1), plots treated with liquid or granular picloram at 0.56 and $1.12 \mathrm{~kg} / \mathrm{ha}$ in 1078 and re-treated with liquid picloram at 0.56 and $1.12 \mathrm{~kg} / \mathrm{ha}$ in 1979,1980 , and 1981 and evaluated in 1982 maintained shoot control comparable to control in plots receiving the initial application of picloram at $2.24 \mathrm{~kg} / \mathrm{ha}$ and re-treated with liquid picloram at 0.56 and $1.12 \mathrm{~kg} / \mathrm{ha}$. Where picloram at $0.56 \mathrm{~kg} / \mathrm{ha}$ was maintaining only 55 to $58 \%$ shoot control 4 years after the original application, the retreatment of picloram liquid at $0.56 \mathrm{~kg} / \mathrm{ha}$ gave 99 to $100 \%$ control. The retreatments of 2,4-D amine at $2.24 \mathrm{~kg} / \mathrm{ha}$, dicamba liquid at $2.24 \mathrm{~kg} / \mathrm{ha}$, and the combination of dicamba $+2,4-\mathrm{D}$ amine at $1.12+2.24 \mathrm{~kg} / \mathrm{ha}$ over the original treatment of picloram liquid at $0.56 \mathrm{~kg} /$ ha resulted in 86,89 and $85 \%$ control, respectively (Table 1).

Dicamba at low application rates is comparable in effectiveness to 2,4-D for leafy spurge control in most cases and rarely is superior to 2,4-D. Dicamba at 6.72 to $8.96 \mathrm{~kg} /$ ha is required for an average of $80 \%$ reduction in vegetative top growth. Even at the higher application rates, recovery and (or) reinfestation is almost complete within 2 years after application. Fall applications seem to be more effective than spring applications, and granular formulations are more consistent than liquid formulations. Dicamba is toxic to most associated grass species, and the high application rates can reduce the grass stand or even kill some grass species. Dicamba at $2.24 \mathrm{~kg} / \mathrm{ha}$ as a retreatment over all herbicide treatments in the repetitive herbicide treatment study by Vore and Alley (38) was not as effective as liquid picloram at $0.56 \mathrm{~kg} /$ ha but considerably more effective than 2,4-D amine at $2.24 \mathrm{~kg} / \mathrm{ha}$ or the combination of dicamba $+2,4-\mathrm{D}$ amine at $1.12+2.24 \mathrm{~kg} / \mathrm{ha}$.

There are differences of opinion among researchers on the use of 2,4-D. Formulations suggested and rates of application vary somewhat between states. It generally is agreed that one application of 2,4-D at 1.12 to $2.24 \mathrm{~kg} / \mathrm{ha}$ applied at or near the bud stage of growth will kill the aboveground stem tissue, will kill young seedlings, and normally will prevent seed production for that season. Rates of 4.48 to $8.96 \mathrm{~kg} / \mathrm{ha}$ have been more effective than lower rates in controlling the top growth, resulting in around $60 \%$ reduction in topgrowth 1 year after treatment. Repeated applications of 2,4-D at $2.24 \mathrm{~kg} / \mathrm{ha}$ or either the amine or ester formulation over a 4-year period have resulted in 25 to $35 \%$ reduction of the original stand. Two applications of 2,4-D per year (spring and fall) will enhance the percentage control obtained, and several years of repeated applications are necessary to reduce the stand. High rates of 2,4-D amine, at 22.4 to $44.8 \mathrm{~kg} / \mathrm{ha}$, have consistently given near $80 \%$ control of the original stand one year after treatment, but reinfestations occur by the second year. Fall treatments are suggested over earlier dates of application.

Glyphosate used on permanent pasture or rangeland sites is not practical because it kills grass, which results in bare areas. However, glyphosate may be the best alternative in some noncrop areas, such as shelterbelts or farmstead land that is to be broken for crop production or pasture renovation where picloram or dicamba residue would not be acceptable.

Herbicide combinations have great value for increasing the spectrum of weed control. There is some limited evidence that leafy spurge control is improved when 2,4-D at 1.12 
$\mathrm{kg} / \mathrm{ha}$ is mixed with picloram at 0.28 to $0.56 \mathrm{~kg} / \mathrm{ha}$, but there was no advantage in using the $2,4-\mathrm{D} /$ picloram mixture with picloram rates above $0.56 \mathrm{~kg} / \mathrm{ha}$. However, the general consensus is that the combination of herbicides evaluated for leafy spurge control is no better than the most effective herbicide at the rate applied in the combination.

\section{Cropland}

Previous research indicates that seeding of a leafy spurge infested area to spring-seeded small grain has little value in reducing the weed stand. However, 2,4-D ester at $0.56 \mathrm{~kg} / \mathrm{ha}$ reduces leafy spurge growth, so the grain can compete effectively with the leafy spurge and hold it in check. The low volatile ester or oil-soluble amine formulations of 2,4-D are the most effective. Spraying in small grains should be combined with a cultural practice. Another option is a post harvest application of glyphosate at 0.84 to $1.12 \mathrm{~kg} / \mathrm{ha}$ after the leafy spurge has grown $10 \mathrm{~cm}$ or more after harvest.

Leafy spurge can be eliminated with less than 2 years of intensive cultivation. Several cultivation and cropping sequences are suggested to reduce or eliminate a leafy spurge stand infesting cropland areas. Most cultivation programs suggest planting a small grain or grass crop in alternate years, so 2,4-D can be used to reduce the weed stand further. Two treatments of 2,4-D per year are important to eliminate leafy spurge effectively.

The use of cropping, cultivation and herbicides to eliminate leafy spurge and prevent reinfestation is covered in another chapter.

\section{Noncropland}

Noncrop areas include utility, highway, pipeline and railroad rights-of-way, industrial sites, fence row and around farm buildings. Soil sterilants can be used on noncropped areas where it is desirable to have bare ground. These include the uracils, ureas, triazines, borates, chlorates, fenac, amitrole and combinations.

The rates of application determine the longevity of control. Soil sterilants may control all vegetation for 2 to 5 years depending upon soil type, rate applied and climatic conditions. Where grass vegetation is desired, picloram, dicamba and high rates of 2,4-D (22.4 to $44.8 \mathrm{~kg} / \mathrm{ha}$ ) can be used. Picloram has a longer soil persistence than either dicamba or high rates of 2,4-D. Retreatment of the 2,4-D and dicamba-treated areas will be required within 1 or 2 years after initial application. Picloram-treated areas may not have to be retreated for 3 to 5 years.

\section{Future research needs}

The interest and research activity in leafy spurge control emphasize the need for evaluation of less expensive practices than are now being utilized, further evaluation of follow-up treatments that may be required after the initial treatment and potential of control methods in different ecological areas, such as forested areas or nearly inaccessible rangelands. 
To understand better the recovery ability of leafy spurge plants, chemical control research should include more extensive studies on the effect of original and repetitive treatments on the underground reproductive root system. Relatively inexpensive herbicides control leafy spurge top growth but do not effectively control the root system. Herbicide translocation and plant physiological studies are necessary to determine why specific herbicides are not effective on the root system, along with additives that may enhance herbicide translocation.

The new application techniques, such as the roller and wick applicators, show promise of reducing the amount of herbicide required by at least $50 \%$ in dense infestations, and herbicide savings of 80 to $90 \%$ seem possible in average infestations. Many variables need to be evaluated, including influence of herbicide concentration, surfactants and speed of application. Equipment and proper wicking materials for specific herbicides must be developed.

Forage production increases resulting from leafy spurge control need to be continued and expanded to assess the long-term response of associated grass species.

Biological control is viewed by some as the ultimate control method on leafy spurge, but chemical and land management techniques must be utilized until biological control is developed. A successful biological control program may require an integration of chemicals, land management and biological agents in a total control program.

New herbicides for control of leafy spurge are not available at this time, and there is little promise of more in the future. The immediate need is to utilize those available in the most efficient and economical manner to suppress the further spread of leafy spurge. Years wasted by waiting for new chemicals or other control methods means that many more hectares will become infested, creating a more serious problem in future years.

\section{Literature cited}

1. Alley, H. P. 1962. Leafy spurge. Wyoming Agric Ext. Serv. Leaflet 49. 4 pp.

2. Alley, H. P. 1965. A promising future for the control of perennial weeds. Down Earth 21 $(1-2): 8-10$.

3. Alley, H. P., G. A. Lee, and A. F. Gale. 1968. The persistence of several compounds over a three-year period, as indicated by the control of leafy spurge. Res. Prog. Rep., West. Soc. Weed Sci. pp $17-18$.

4. Alley, H. P. 1979. Chemical control of leafy spurge. Pages 53-66 in: Proc. Leafy Spurge Symposium, Bismarck, N. D., June 26-27, 1979. North Dakota State Univ. Coop. Est. Serv., Fargo. 84 $\mathrm{pp}$.

5. Alley, H. P. and N. E. Humburg. 1979. Response of leafy spurge to several herbicide treatments. Res. Prog. Rep., West. Soc. Weed Sci. pp 18-19.

6. Alley, H. P. and N. E. Humburg. 1981. Wyoming weed control guide - 1981. Wyoming Agric. Est. Serv. Bull. 442R. 63 pp.

7. Alley, H. P., R. E. Vore, and N. E. Humburg. 1981. Herbicide combinations and comparison of Herbi vs conventional application for leafy spurge control. Res. Prog. Rep., West. Soc. Weed Sci. p 17.

8. Bakke, A. L. 1937. Control of leafy spurge - Euphorbia esula L. Iowa State Agric. Esp. Stn. Res. Bull. 222. 29 pp. 
9. Bohmont, D. W. 1952. Control of Russian knapweed, leafy spurge, Canada thistle and white top with growth regulating compunds. Res. Prog, Rep., West. Weed Contr. Conf. pp 12-13.

10. Bowes, G. and E. S. Molberg. 1976. Herbicide control of leafy spurge. Leafy Spurge Symposium. Regina Res. Stn. 3 pp.

11. Bybee, T. A. 1981. Leafy spurge control and reestablishment after herbicide treatment. Ph.D. Thesis, North Dakota State Univ. 88 pp.

12. Derscheid, L. A. and L. J. Wrage. 1972. Control and elimination of leafy spurge. South Dakota State Univ. Est. Serv. F.S. 449. 4 pp.

13. Erickson, L. C. 1960. The relative efficiency of 10 herbicides applied at high rates for control of leafy spurge. Res. Prog. Rep., West. Weed Contr. Conf. pp 4-5.

14. Fabricius, L. J. 1959. Chemical control of leafy spurge. Res. Prog. Rep., West. Weed Contr. Conf. p 3.

15. Furrer, J. D., A. R. Martin, F. W. Roeth, and R. S. Moomaw. 1981. A 1981 guide for herbicide use in Nebraska. Nebraska Ext. Serv. E.C. 81-130. 28 pp.

16. Hanson, H. C. 1936. Leafy spurge. North Dakota Est. Serv. Circ. 141. 4 pp.

17. Heikes, E. E. 1964. Tordon and other herbicides - field testing for the control of deep-rooted perennial weeds in Colorado. Down Earth. 29:9-12.

18. Higgins, E. H. and G. D. Ames. 1965. Leafy spurge identification and control. Idaho Ext. Serv. Bull. 438. 5 pp.

19. Jeffrey, S. J. and L. R. Robinson. Know and control leafy spurge in Nebraska. Nebraska Ext. Serv. E.C. $69-186.8$ pp.

20. Krall, J. L. 1952. Effect of 2,4-D, ammate and other herbicides on leafy spurge. Res. Prog. Rep., West. Weed Contr. Conf. p 9.

21. Lueschen, W. C., J. D. Furrer, and A. R. Martin. 1981. Univ. Nebraska Proc., 1981 Crop Prot. Clinics. pp 177-184.

22. Lym, R. G. and C. G. Messersmith. 1981. Low volume picloram application for leafy spurge (Euphorbia esula L.) control. Abstr. 108, Weed Sci. Soc. Am. p 50.

23. Lym, R. G. and C. G. Messersmith. 1982. Roller and wick application of picloram for leafy spurge control. Res. Rep., North Cent. Weed Contr. Conf. 39:60-63.

24. Mitich, L. W. 1967. Control of leafy spurge, field bindweed and western snowberry with Tordon herbicides. Down Earth 23:8-11.

25. Mitich, L. W. 1969. Chemical control of leafy spurge and field bindweed. Proc. North Cent. Weed Contr. Conf. 24:65-67.

26. Mitich, L. W. 1971. Spring and fall evaluations of herbicides on leafy spurge. Res. Rep., North Cent. Weed Contr. Conf. 28:65-66.

27. Mitich, L. W. 1972. Three years leafy spurge control trials with herbicides. Res. Rep., North Cent. Weed Contr. Conf. 29:32-33.

28. Mitich, L. W. 1973. Leafy spurge control. North Dakota State Univ. Circ. W-295. 4 pp.

29. Messersmith, C. G. 1974. Fall applications of dicamba, picloram and Dowco 290 for leafy spurge control. Res. Rep., North Cent. Weed Contr. Conf. 31:15-16.

30. Messersmith, C. G. 1973. Leafy spurge control with spring and fall applications. North Cent. Weed Contr. Conf. 30:29.

31. Messersmith, C. G. and R. G. Lym. 1981. Dicamba for leafy spurge and Canada thistle control. Res. Rep., North Cent. Weed Contr. Conf. 37:62. 
32. Messersmith, C. G. and R. G. Lym. 1981. Roller and wick application of picloram for leafy spurge control. Down Earth 37(2):9-12.

33. Messersmith, C. G. and R. G. Lym. 1981. A pipe-wick herbicide applicator for perennial weed control in pastures. Res. Rep., North Cent. Weed Contr. Conf. 38:36-37.

34. Robinson, L. R. 1969. Leafy spurge control. Res. Rep., North Cent. Weed Contr. Conf, 26:17-20.

35. Shafer, N. E. 1954. Soil applications of 2,4-D for control of deep-rooted perennial weeds. Proc. North Cent. Weed Contr. Conf. 11:56-59.

36. Timmons, F. L. 1970. A history of weed control in the United States and Canada. Weed Sci. 18:294307.

37. Vore, R. E. 1979. Repetitive herbicide treatment program for control of leafy spurge. M.S. Thesis, Univ. of Wyoming, Plant Sci. Div. 45 pp.

38. Vore, R. E. and H. P. Alley. 1981. Leafy spurge (Euphorbia esula L.) Wyoming chemical control research. Univ. Wyoming MP-46R. 30 pp.

39. Vore, R. E. and H. P. Alley. 1981. Leafy spurge - Menace to the west. Down Earth 36(3):2-5.

40. Vore, R. E. and H. P. Alley. 1982. Unpublished data.

41. Warden, R. L. 1955. Leafy spurge control. Res. Prog. Rep. West. Weed Contr. Conf. p 8. 